\title{
In the Shadow of Crisis: Economic Orthodoxy and the Response of Global Labour
}

\author{
Stephen McBride, McMaster University, Hamilton, Canada \\ Scott Smith, McMaster University, Hamilton, Canada
}

\begin{abstract}
This article examines the role played by global labour organizations in formulating a policy response to the global economic crisis. The global crisis that grew out of the contradictions and failure of existing hegemonic ideas meant that for the first time in several decades a possibility existed of rethinking the neoliberal economic strategy that has guided policymaking in most of the world. The on-going crisis and the responses to it provide an occasion to revisit accounts of policy change and to reflect on the social forces stimulating change and those representing consolidation.
\end{abstract}

\section{KEYWORDS}

economic crisis, global labour, labour strategies, policy alternatives, policy change

\section{Introduction ${ }^{1}$}

This article examines the role played by global labour organizations ${ }^{2}$ in formulating a policy response to the global economic crisis. The global crisis that grew out of the contradictions and failure of existing hegemonic ideas meant that for the first time in several decades a possibility existed of challenging the neoliberal economic strategy that has guided policy-making in most of the world. The ongoing crisis and the evolving responses to it provide an occasion to revisit accounts of policy change and to reflect on the social forces stimulating change and those representing consolidation.

According to the tenets of neoliberal economics, crises such as this were not supposed to happen (Stiglitz 2011). The initial reaction of states and international organizations was to suspend practice based on neoliberal theory and, instead, to engage in emergency reactions that included bailouts and de facto nationalization of banks and financial institutions. Significant public spending to sustain demand was also undertaken around the world in order to combat the crisis. A global recession, alleviated somewhat by these emergency measures, followed the financial crisis and credit-crunch. However, at the first signs of 
recovery these policies were succeeded by austerity measures and a renewed assault on social program spending.

The situation remains unstable and subject to change. At Camp David on 19 May 2012, G8 leaders called for a growth-led, rather than austerity-induced, path to economic recovery. The International Trade Union Confederation (ITUC) and the Trade Union Advisory Committee (TUAC) to the Organisation for Economic Co-operation and Development (OECD), two of the most important global labour organizations, welcomed the change in rhetoric but cautioned that states must strive to implement the growth-led path to recovery: 'the G8 has turned away from austerity and depression and toward jobs and growth. The member countries now must take action to make the commitments at Camp David into reality. ${ }^{3}$ On the other hand, according to its Finance Minister, Germany continued after the G8 meeting to position austerity as an essential pre-condition for growth: 'Fiscal consolidation is the precondition for our goal which is more growth' (Globe and Mail, 23 May 2012: B10). Indeed, within much of the European Union a new Treaty on Stability, Coordination and Governance in the Economic and Monetary Union had already been signed requiring, when ratified, national budgets to be in balance or in surplus. If a member state deviates from this rule, an automatic correction mechanism will be triggered. Those signing ${ }^{4}$ agreed to incorporate the 'balanced budget rule' into national legislation, preferably at the constitutional level. ${ }^{5}$ This suggests the battle of ideas and economic strategies will be complex and that the technique of locking-in policy preferences to make them less susceptible to political change will be a continuing feature of the post-crisis neoliberal strategy.

That capital, its organizations, and their sympathetic neoliberal political elites would seek a return to the status quo once the initial crisis had stabilized to a degree, or seek to use the crisis to further their long-standing agenda, should not be surprising. Yet there are other possible scenarios arising out of the post-crisis macroeconomic response. The first is a reversal of the pre-crisis orthodoxy and the establishment of some form of neo-Keynesianism involving more state spending and social and economic intervention and regulation. This would constitute a paradigm shift analogous to that which occurred in the 1970s when Keynesianism gave way to neoliberalism (Hall 1993). A second scenario describes a period of contestation, perhaps prolonged, in which an untidy hybrid of elements of neoliberalism and a neo-Keynesian alternative could be found in uneasy co-existence. Third, the neoliberal status quo might be restored. Finally, there might be an intensification of neo-liberalism with a renewed assault on the role of the state and the transfer of more of its authority to private markets. ${ }^{6}$ (In Chart 1 we schematically identify these respective scenarios; Chart 2 attempts to define the content of the neo-liberal and neo-Keynesian options).

\begin{tabular}{|c|c|c|c|}
\hline \multicolumn{4}{|c|}{ Chart 1. Post crisis scenarios and options } \\
\hline $\begin{array}{l}\text { Paradigm Shift: } \\
\text { Neo-Keynesian } \\
\text { alternative }\end{array}$ & $\begin{array}{l}\text { Contested } \\
\text { Hybridization: Neo- } \\
\text { liberalism and neo- } \\
\text { Keynesianism }\end{array}$ & $\begin{array}{ll}\text { Neo-liberal } & \text { Status } \\
\text { Quo restored } & \end{array}$ & $\begin{array}{l}\text { Intensified } \\
\text { liberalism }\end{array}$ \\
\hline
\end{tabular}

Source: Authors 
Our focus on global labour, as a prospective source of alternative ideas to the prevailing neoliberal economic model, is stimulated by a policy change literature that suggests that dramatic changes in policy approach are associated with, though certainly not guaranteed by, crises (Kuhn 1962, Hall 1993). Ideational change is central to much of this literature, but the phenomenon of paradigm shift cannot be analyzed solely at the level of ideas, in terms of the superiority of one set of ideas over another. Hall (1993: 280) argued that the replacement of one paradigm by another will be as much a sociological or political phenomenon as a scientific one, and the outcomes are far from certain. ${ }^{7}$ There are operational difficulties in applying this approach to change. Vivien Schmidt (2011: 39) has observed that it can be difficult to know when paradigms have shifted and to understand why and how this has occurred. ${ }^{8}$ Most policy literature tends to emphasize policy continuity, or path-dependency, at the expense of a more nuanced account of the sudden shift in policy ideas and instruments (see for example Hacker 1998, Pierson 2000). The paradigm shift literature alerts us to the possibility of fundamental change that may sometimes occur, mostly under crisis conditions in which ideas play a key role. ${ }^{9}$

In this article we identify global labour as a social actor that is potentially capable of developing an alternative to the current paradigm. We do not exaggerate its power or influence in the global arena but are mindful that it does have a variety of opportunities and strategies available to it. Key to these opportunities seems to be an expanding range of institutional access points, for instance via the G20. ${ }^{10}$

At the level of ideas, neoliberalism is based on the promotion of expanded private markets and market relations, leading to great insecurity for labour, and systemic instability. Changes within the accumulation process associated with neoliberalism include the emergence of financialization and reliance on debt to stimulate (or simulate) prosperity, and an enhancement of 'accumulation by dispossession' and exploitation (Harvey 2008). This is typically accompanied by budgetary austerity (in the form of debt/deficit fixation, an end to demand management, and declining generosity of social programs), de/re-regulation both at home and in the international economy, and privatization in multiple dimensions. Together these state interventions reinforce the inegalitarian impact of markets and privilege the interests of capital over those of labour.

Schematically, this is represented in the following chart as a package of dimensions though, of course, the mutually reinforcing relationship between them is not captured by the chart. A fully developed alternative to neoliberalism would involve movement on all dimensions to the opposite side of the continuum. Less developed change, leading to the hybrid scenario outlined in Chart 1, might involve more limited movement along the continuum on all or some dimensions. We draw on these categories in analyzing global labour's response to the crisis and in trying to determine whether those responses amount to an alternative paradigm or simply modifications to the existing one. 


\begin{tabular}{|c|c|c|}
\hline \multicolumn{3}{|c|}{ Chart 2. Schematic representation of Neoliberalism and a Neo-Keynesian alternative } \\
\hline Neo-Keynesian paradigm & Contested zone & Neoliberal package \\
\hline Re/regulation & \multirow{8}{*}{ 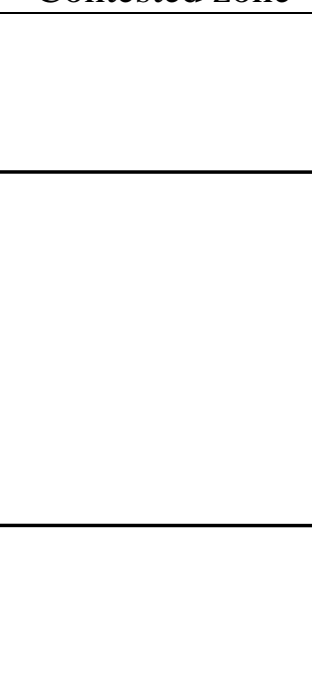 } & $\begin{array}{l}\text { Privatization and } \\
\text { deregulation }\end{array}$ \\
\hline Capital controls & & Capital mobility \\
\hline Managed trade & & Free trade \\
\hline Full-employment & & Inflation control \\
\hline Fiscal stimulus & & $\begin{array}{l}\text { Fiscal consolidation and } \\
\text { constraint }\end{array}$ \\
\hline $\begin{array}{l}\text { State intervention to } \\
\text { modify market outcomes; } \\
\text { greater role in economic } \\
\text { management }\end{array}$ & & $\begin{array}{l}\text { State reinforces market } \\
\text { outcomes }\end{array}$ \\
\hline Equalization & & Market-driven inequality \\
\hline $\begin{array}{l}\text { Employment protection } \\
\text { and security }\end{array}$ & & $\begin{array}{l}\text { Flexibilization of labour } \\
\text { markets }\end{array}$ \\
\hline
\end{tabular}

Source: Authors

\section{Structural Weakness of Labour}

In seeking to influence events at the global level, labour faces the handicap that, over the course of the neoliberal era, the national foundations of global labour organizations have been significantly diminished. One indicator is union density, or the percentage of the labour force that is organized into unions. Chart 3 records declining union density in the OECD area for a forty-year period from 1975.

Chart 3. Union membership, OECD Area, 1975-2007

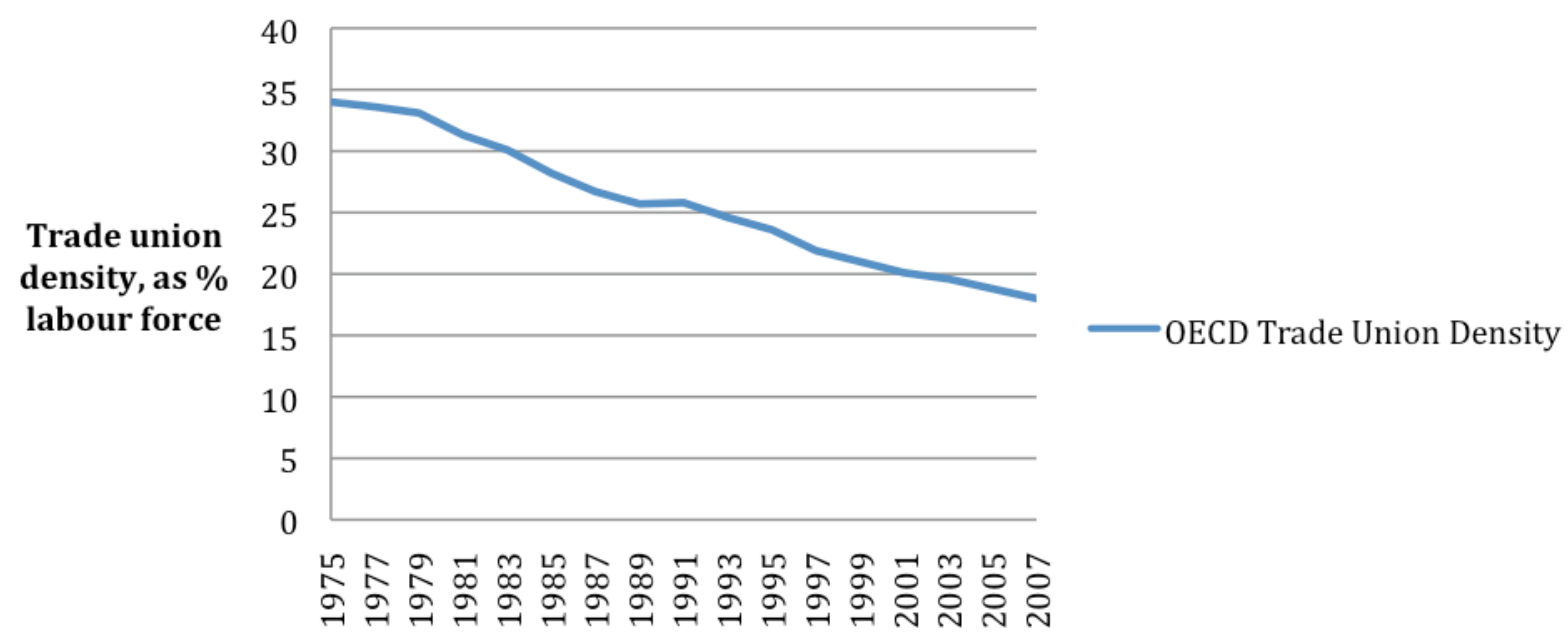

Source: OECD website: stats.oecd.org 
Similarly, strikes as an expression of union power, have declined steadily over the same period. The OECD (2007) noted that: 'In the OECD area, the strike rate has roughly halved in each decade since the early 1980s'. Politically the situation is no better. At various points in the past, the strength of labour's political arm - socialist, communist and social democratic political parties - or its industrial arm, trade unions capable of being mobilized into mass or political action, was such that policies of concessions were pursued by economic elites and their right wing political counterparts. Indeed the social dialogue institutions in which labour is represented at the global level, the International Labour Organization (ILO) and the OECD's TUAC, were products of precisely such calculations. However, labour's great political forces of the last century are either disbanded or pale shadows of their former selves, as with the communist parties of western Europe; or else are ideologically thoroughly integrated into the prevailing paradigm, as with almost all social democratic parties. Few electoral vehicles carry global labour's alternative paradigm at the national level. Recent antiausterity electoral results in France and Greece, and continued social unrest across much of Europe, suggest that labour may find new alliances in the post-crisis period. And as one senior ILO official notes, trade unions in the global south have sometimes been successful in building these broader alliances. 'So you take a country like Brazil: they have always had a broader alliance, where [unions] have always been open to other social movements' (confidential telephone interview, ILO official, 7 November 2012).

The growing power of international financial capital, the pressure associated with shareholder profits, and a permissive regulatory environment favourable to international capital have permitted employers - especially multinational corporations - to call for more 'flexible' labour markets and wage roll-backs while increasing profitability (Peters 2011: 75). A growing reliance on casual and temporary workers, coupled with a loss of union membership, has sent unions into decline and, in some cases (such as the Netherlands), led to the removal of union representatives from the governance boards of major corporations, thus diminishing certain types of co-determination and social dialogue and the space available for exerting labour influence (ibid: 83). There are exceptions to this trend, for example in Germany, and in the case of the European Works Councils (ECW) which have been strengthened by a 2009 European Commission amendment. These institutions arguably provide a small window of opportunity through which unions can influence corporate decision-making (Munck 2002; Huijen, Whittall and Knudson 2007; Lansbury 2009).

\section{Global Labour as a Potential Agent of Change}

Global labour continues to exist as an organised force even if its constituent parts are weakly institutionalized at the national level. Global labour has sought to build upon its long-standing efforts to shape the debates and practices surrounding work and employment (Lansbury, 2009: 331-3) by influencing current debates about the future of the global economy. This is a potentially important sphere of activity. The key entities are the International Trade Union Confederation, the Trade Union Advisory Committee to the 
OECD and the Global Union Federations (GUFs), representing a large share of global labour, and which interact with labour representatives at the International Labour Organization, through the ILO's Bureau for Workers' Activities (ACTRAV).

The ITUC, formed when the International Confederation of Free Trade Unions (ICFTU) and World Confederation of Labour dissolved in November 2006, is now the world's largest trade union body representing 175 million workers in 151 countries. Under the umbrella of the Council of Global Unions, itself established in 2007 as a means to generate greater coordination among global unions, ITUC has joined TUAC in several leading publications, including Exiting from the Crisis: Towards a Model of More Equitable and Sustainable Growth (European Trade Union Institute [ETUI] 2011). Exiting the Crisis builds on the ILO's Decent Work agenda and provides a platform for the kind of paradigmatic changed envisioned by global labour. The Trade Union Advisory Committee has official consultative status with the OECD. TUAC was formed in the wake of the European Recovery Programme (the Marshall Plan) in 1948 as an interface between trade unions and the OECD. Through its 58 national trade unions centres representing 66 million workers, TUAC has more recently coordinated labour input into the G8 summits and acted on a variety of issues related to labour market policy across OECD states. Since the crisis the G20 has become a more important forum for TUAC (confidential telephone interview, TUAC official, 25 July 2012). Together ITUC and TUAC bring considerable institutional resources through their formal associations with the ILO and OECD, but they also command a significant degree of influence through affiliated national level unions bridging North and South.

Hennebert and Bourque (2011) provide a useful if schematic account of ways that global labour strategically responded to the global economic crisis: as insiders working within international institutions like the ILO and OECD; as outsiders exerting influence through research and activism largely beyond the workings of the ILO and OECD; and in their lobbying for labour clauses in free trade agreements. Here we focus on the insider and outsider strategies, ${ }^{11}$ and, in each of the following sections, document labour's strategy followed by an analysis of the degree of change to the dominant neo-liberalism that it represents and an assessment of how much impact it has had.

The insider/outsider distinction is analytically useful, but we recognize that it may overlook the way global labour actually works through balancing and interacting between insider and outsider positions. As one global labour official put it: 'we need to do both...You can bring a very powerful message by being inside an institution, but the reason we get as far as we do, in many countries and cases, is because they are worried about unions' strength in terms of electoral processes...' (confidential telephone interview, ITUC official 17 July 2012).

\section{Global Unions as Insiders in International Organizations}

Global unions are represented on two major international organizations: the OECD through its Trade Union Advisory Committee, and on the tripartite (government, 
employers, labour) International Labour Organization. Unsurprisingly they seek to take advantage of these positions to influence emerging global policy.

The International Labour Organization was founded in 1919 as a response to the social tensions triggered by war and revolution. It was designed to 'address workers' interests within the confines of the modern capitalist labour market' (Vosko 2000: 20) and thus focused on the amelioration of capitalism's effects rather than its replacement. The ILO is committed to social dialogue; from its inception the organization was tripartite, being composed of representatives of business, labour and government. Similar to the OECD, the ILO positions itself as an organization responsible for the development and dissemination of expert knowledge and common standards achieved through voluntary agreements, though with few enforcement mechanisms beyond moral suasion. During the Great Depression, the ILO did take a stance in attempting to devise global social policy responses to the global financial, economic and employment crisis by pushing for internationally coordinated public works schemes to create jobs (Endres and Fleming 1996, Hughes and Howarth 2012). However, its record in recent decades has been less impressive: failing to resist US pressures to adopt the 1990s orthodoxy of the neoliberal Washington consensus, undergoing encroachment from more robust international organizations like the World Bank and International Monetary Fund, and taking refuge in populist formulae ${ }^{12}$ (Standing 2010). Nevertheless, it was not unreasonable to hope that the ILO might recover some of its former role as a generator of alternative responses to crisis. Hughes and Haworth (2010: 43) point out that the ILO's origins, structure (tripartite and based on social dialogue), and traditions lend themselves not to radicalism but rather to 'challenge policy settings and outcomes' within the capitalist system. Its expert research on employment and labour market matters and earlier identification of a looming crisis has clearly resulted in enhanced prestige and recognition from the G20 (Hughes and Haworth 2012).

The ITUC/TUAC/GU task force publication, Exiting from the Crisis, conceives of the ILO's Global Jobs Pact as a 'prescription for recovery:' a social protection floor, combined with minimum wage guarantees and collective bargaining rights forms the basis for income-led growth (ETUI 2011: 111). The Global Jobs Pact, which resulted from the $98^{\text {th }}$ session of the ILO in June 2009, suggested the ILO could indeed devise a global social policy response to contemporary crisis. Reflecting the tripartite framework between governments and labour/employer organizations, the Jobs Pact proposed to deal with the global recession by drawing on social dialogue to achieve an internationally agreed upon set of labour policies that seek to minimize the gap between economic recovery and employment recovery. The Jobs Pact was (and is) an attempt to use a core set of international labour standards to stem the flow of wage cuts (see ILO 2011: 210). It outlines a set of principles and a portfolio of recommended policies from which individual countries could create a package suitable to its own priorities, but which would be designed to put 'full and productive employment and decent work at the heart of the crisis responses' (ILO 2009: 5). Unsurprisingly the recommendations and principles are cast at high level of generality.

The Pact draws on the ILO's earlier Decent Work agenda - itself a rather vague programmatic approach that aims to provide full employment for every able-bodied man and 
woman 'promoted through aid, development and investment measures.' Decent Work is measured by four strategic objectives:

1. International labour standards that guarantee worker and workplace rights;

2. Employment and income opportunities through demand-led growth underpinned by macro-economic counter-cyclical policies; vocational and education policies that contribute to the growth of 'green' jobs;

3. Social protection and social security (e.g., through policies that extend and prolong EI coverage);

4. Social dialogue and tripartism. ${ }^{13}$

The integrated approach of the ILO Global Jobs Pact remains the core apparatus of an income-led growth model around which global unions are structuring much of their joint activity. This is a sphere of activity where global labour organizations like ITUC can make an identifiable contribution. Essentially, the strategy is to capitalize on the legitimacy and resources of a tripartite institution like the ILO to make gains that may otherwise be unachievable. The ILO houses the Bureau for Workers' Activities (ACTRAV), a technical department that plays a central role in building and strengthening union capacity through research and networking. ACTRAV officials played a role in shaping the ILO's response to the global economic crisis by promoting public investment policies favourable to a growthled strategy (confidential telephone interview, ILO official, 7 November 2012). ACTRAV's union outreach coupled with its close proximity to the ILO Governing Body means that global labour can influence ILO policy.

As a case in point, ACTRAV and ITUC officials gathered in Lomé, Togo in March 2012 to put into motion elements of the ILO's Decent Work agenda in Africa. ${ }^{14}$ These elements chiefly revolve around establishing a social protection floor in countries where public health issues like HIV/AIDS intersect with campaigns to promote decent work, in particular for domestic and precarious workers. Ultimately, in this 'insider' capacity, the ITUC operates within the ILO's mandate for global policy shift - here focusing on one of the ITUC's overlapping priorities, precarious work - while drawing on resources like ACTRAV for support in implementing local policy goals. In turn, ITUC affiliates across the world help to deploy the ILO's Decent Work agenda in context-specific ways that may appeal to the real economic difficulties facing certain locales, thus boosting the ILO's presence and relevance. Rather than challenging the forces of economic globalization directly, the ITUC's work in sub-Saharan Africa is a good example of how global labour strategy works to overturn specific conditions that hamper worker rights, collective bargaining, and decent living.

The ITUC has also been consulting closely on important ILO publications. Social Protection Floor for a Fair and Inclusive Globalization (ILO 2011b) endorses the earlier Jobs Pact document and echoes themes driving the current global labour agenda: promoting the guaranteed access to national universal health care; basic income security for the weak, women and children, and the elderly; and active labour market policies. Without overstating 
the ITUC's role in this multilateral effort, it is evident that the ILO consults with global labour to develop a more socially-inclusive and economically-dynamic development model that forms the basis of a more 'inclusive' globalization (ibid: ix).

However, the fact that ILO documents are the product of tripartite discussion in which the other partners have mostly been on the side of neoliberal political economy means that the creation of an alternative vision is limited by the nature of labour's partners. The level of generality in which documents like the Jobs Pact are formulated, together with the range of options contained within the document, and the fact it is dependent on states for implementation, means that differences between the partners are somewhat camouflaged. As one ILO official noted, 'there's always a value in cooperating, but there's also a value in a plurality of ideas. One of the reasons why the crisis of 2008 came as such a shock and surprise was that there was a kind of monopoly on interpreting how the economy should be structured' (confidential telephone interview, ILO official, 7 November 2012).

Because of its technical expertise on global labour issues, the ILO remains an important venue for the voice of global labour. Indeed, Decent Work forms the basis of a coordinated effort by the ITUC and TUAC to shape a future global economic order. Labour enjoys structured access to the ILO, and cooperation between ACTRAV and ITUC affiliates around the world help anchor socially-inclusive development models. Yet discontent persists. Although the Council of Global Unions played a pivotal role in bringing the ILO and the Jobs Pact to the April 2009 G20 Labour Ministers' summit, there were concerns within the Council that the summit had too much of a feeling of 'business as usual'..$^{15}$

Institutional configuration based on dialogue and negotiation with social partners in business and government produces contradictions for labour. The need to adopt consensus documents limits the scope of the agenda that can be pursued through the 'insider' strategy. Yet, paradoxically these institutional spaces may permit global labour the access it needs to push for lasting change to the global economic system. The TUAC, for example, is able to parlay its access to the OECD and to high-level meetings at the G20 to forward policy concerns from its labour partners in the Global South. Moreover, consultative status inside the OECD does not preclude cooperation with labour outside the organization and the development of criticism of the OECD (confidential telephone interview, TUAC official, 25 July 2012).

In that sense one question for global labour is whether it can more effectively bring about a plurality of ideas conducive to promoting a more equitable global economy outside its established positions in the ILO and OECD.

\section{Global Unions as Outsiders: Pressuring International Organizations}

Global labour has attempted to lobby other international fora it views as having a key role in developing responses to the crisis. This has led to some demonstrable success. The ITUC, for instance, claims it has been able to persuade the G20 to include public declarations on labour market issues of interest to global labour: 
Well, to start with at every G20 summit certainly from London onwards there was an improvement in the conclusions of the G20 declaration and communiqués which was due to our lobbying. Even in the worst ones, which from our perspective was the one in 2010, those G20 communiqués included quite good paragraphs on the first page, let's say, about employment, which we know at the start of the meetings were not even there at all, or at the end of the text. We've been able to get them to prioritize employment and to put there in a very positive point of view - not jobs at any cost, they're talking about quality employment, good jobs and decent work (confidential telephone interview, ITUC official, 17 July 2012).

This personal account from an ITUC official reveals the lobbying processes through which global labour has been able to advance a core policy structured on the ILO's Decent Work agenda. Global unions work through 'task forces' on issues related to employment with ministerial delegates to the G20. These task forces tend to be the result of informal meetings between union officials and ministerial representatives (confidential telephone interview, TUAC official, 25 July 2012). The G20 task forces also include representatives from TUAC and the Global Union Federations (GUFs). It is clear, therefore, that a harmonized effort between the ITUC, TUAC and other labour partners is brought to bear on the G20 both formally - especially through G20 communiqués - and also informally via networks generated by a set of common issue areas.

Indeed, for our purposes it is not necessary to separate the priorities and perspectives of the individual labour groups (ITUC, TUAC, the Global Unions) because many of the statements from the labour groups are joint statements. For instance, the majority of ITUC statements are joint statements with at least the TUAC; and almost all of the TUAC statements are 'in partnership' with the ITUC and Global Unions. An examination of ITUC and TUAC documents (ITUC 2008, 2009, 2010, 2011, 2012, 2013; TUAC 2008, 2009, 2010, 2013) from 2008 onwards reveals the articulation of a broadly Keynesian or neo-Keynesian response to the crisis as a conscious alternative to a paradigm depicted as being supportive of 'unfettered financial markets and...self regulation' (ITUC 2008). In the context of the crisis, early documents accepted the need for governments to recapitalize the banks while simultaneously criticizing the socialization of private sector debt that was involved. Later documents switched to an emphasis on reforms to financial governance in order to make such crises impossible in the future. The need for fiscal stimulus, rather than consolidation or austerity, was a common feature of labour declarations and is nicely encapsulated in a TUAC (2008: 3-4) statement calling for increases in aggregate demand 'of sufficient magnitude to revitalize the real economy: employment, wages, and household disposable incomes'. Such formulations indicate that at least in the current period global labour espouses a classic Keynesian view of unemployment.

As a corollary, the continued attachment of some international organizations, the OECD and IMF amongst them, to structural explanations of labour market problems (such as 'rigidities' within the labour market) come in for regular criticism. Increased social 
spending under the rubric of a social protection floor is endorsed. A more interventionist and regulatory role for the state is part of this vision, but as much emphasis is placed on the reform of global governance institutions. The IMF and other organizations are singled out for criticism while the ILO is endorsed and its expertise in labour matters, global labour argues, should be recognized and utilized. At the same time, labour has called for inclusion in global governance organizations wherever important economic decisions are being made.

These declarations by global labour, often in chorus, suggest a gradual movement toward themes identified with the neo-Keynesian alternative in Chart 2. There remains subtle omissions. Declarations by global labour place comparatively less emphasis on privatization, capital controls (except where finance is concerned), and the free trade system. As noted below, the relative inattention to these issues is problematic in that the combination of mobility of goods, services and capital, in a context of increased privatization, has proved disadvantageous for labour throughout the neoliberal period. Addressing these issues might be fundamental to re-instituting a form of Keynesianism. Nevertheless, global labour has articulated a form of Keynesianism that presents an alternative to the neoliberal paradigm associated with the crisis.

For example, at the 2010 congress of the ITUC a resolution on 'Changing Globalisation' articulated similar themes calling for the rejection of neoliberalism and for fundamental change (ITUC 2010). Part of this was a call for the implementation of the ILO's Global Jobs Pact as part of a rebalancing between labour and capital. Similarly, ITUC advocated 'fundamental reform in the internal governance of intergovernmental organisations, especially the International Monetary Fund (IMF), the Financial Stability Board (FSB), the World Bank and the World Trade Organisation (WTO), to improve the representation of developing countries and guarantee full democracy, transparency and consultation in their decision-making processes'. The document reiterated the need for working people to 'have a seat at the table' through a formal trade union advisory role. It also recognized that the neoliberal ideology of these international organizations was partly responsible for the crisis, that their mandates needed to be changed, and proposed a leading role for the ILO (ITUC 2010: 2). There was some analysis of the role of multilateral and regional trade and investment agreements and suggested reforms to these to protect public services and eliminate protectionist measures against developing countries.

In 2011 the Global Unions, comprising the ITUC, the sectoral Global Unions Federations and the TUAC presented a statement to the 2011 meetings of the IMF and World Bank. Recognizing that previous appeals had fallen on deaf ears and that the IFIs were leading the drive to fiscal consolidation, or austerity (reversion to the neoliberal status quo or its intensification - see Chart 1), the unions sharpened their criticism of the role played by the IFIs. The statement called on them to defer to the ILO in labour market matters, rather than urging labour market flexibility on states, renewed calls for a financial transactions tax, and to 'demonstrate a decisive break with the failed "Washington Consensus" policy paradigm'. ${ }^{16}$

These views were further developed in Exiting the Crisis, a publication emanating from a task force to establish a 'new growth model' - in effect a first step to reviewing and 
providing an alternative to the prevailing economic paradigm of 'market fundamentalism' (ETUI 2011: 20). This initiative recognizes the failure of labour's earlier attempts to impress on international organizations and national governments the need to maintain stimulus measures to offset the risk of a double dip recession or full blown depression: 'A dramatic swing in the direction of state action has been swiftly followed by an equal and opposite clamour for immediate fiscal consolidation.....austerity policies are back with a vengeance' (ibid: 22). After the rather modest statement that working people require 'a voice in determining their futures', the document goes on to outline a program based on full employment, rising incomes and labour standards for developing countries, an environmentally sustainable economic growth model, and greater income equality as a route to greater social cohesion (ibid: 23).

It was already clear by 2010 at the international and national level that whatever enthusiasm may have existed for employment-led crisis recovery plans generated through these cooperative arrangements had dampened. Support for expanding stimulus programs to accommodate a jobs-led growth plan was met with entrenched political opposition. One senior ITUC official appraised the situation in this way: 'But then I think we can say starting in 2010, and this was really confirmed at the Toronto summit in June of 2010, that [job creation initiatives] were essentially scaled back and governments did an about-face and put the emphasis on fiscal consolidation, i.e., deficit reduction' (confidential telephone interview, ITUC official, 17 July 2012). After a brief movement in the direction of Keynesian stimulus policies, government and international organizations reverted to, and in some cases intensified, their attachment to neoliberalism (see Charts 1 and 2).

In this context, the rather vague Jobs Pact made little headway against arguments that prompted a return to the 'comforting nostrums of economic orthodoxy' (ETUI 2011). Austerity measures were widely and swiftly enacted to reduce government deficits. Even states like Germany cut deficits rather than adopting counter-cyclical measures to buffer the effects of recession.

Although the Jobs Pact was endorsed by the ITUC's $2^{\text {nd }}$ General Congress in Vancouver in 2010, it was described by the Council of Global Unions as falling short of expectations. The ILO itself has conceded its proposals have been largely ineffective:

Among the countries that responded to the crisis, only limited elements of the proposals in the Global Jobs Pact were adopted. One focus was on infrastructure investment, but without much effort to make this employment-intensive. Some countries saw an increase in social dialogue, but more in an attempt to calm down workers than to actually find collectively agreed solutions. In terms of labour standards, the crisis intensified the discussion, but few concrete changes have materialized thus far (ILO 2011: 64).

The 'insider' strategy and incorporation of some of its elements into 'outsider' strategies therefore presents a dilemma for labour. If the ILO is to champion a new global governance structure it must do so with the cooperation and agreement of the social 
partners: labour, government and business. This implies a degree of moderation and compromise that may produce vague and general documents that only partially reflect the aspirations of labour. And, as with the Global Jobs Pact, it still may prove ineffective as far as implementation is concerned. Yet, it is also true that the ILO has achieved some recognition at the G20 for its contributions to labour research and program development. The organization gets occasional mention in communiqués of the G20 Leaders and Finance Ministers, whilst the ITUC and TUAC are not mentioned at all. In G20 Labour Ministers' communiqués the ILO is repeatedly cited and ILO conventions are often supported.

Stepping outside the insider constraint presents its own dilemmas. Proposals can be somewhat more radical, but they also run the risk of being ignored. In Getting the World to Work (Global Union Federation 2009), global labour attempted to come to grips with the question: how can trade unions mobilize a policy vision to deal with mass global unemployment and other issues related to public welfare that goes beyond 'tinkering with regulation and repairing broken models of free trade'? As a collection of voices representing the global trade union leadership, the document's centrepiece is an abridged version of the London Declaration, a statement prepared for presentation to the London G20 summit in April 2009. The Declaration warned '[without] a radical response by governments and international institutions the unemployment crisis will be transformed into a social and, ultimately, political crisis'. ${ }^{17}$

Priorities set out in the Declaration included a new governance structure for global economic trade, a new economic model for the creation of jobs, tighter rules for controlling global financial markets, and a green growth agenda. The goal is a new economic order governed by tighter financial market regulation and employment-based policies designed to get people working. The Council of Global Unions wants leaders of G20 nations to develop and maintain a political agenda around making social issues just as salient as economic ones. Calling for a 'paradigm shift in policy making' (London Declaration: 3), the global unions focused on a new global architecture to control financial markets, a new economic development model, and an end to policies that had polarized income distribution in recent decades. This thrust was to be operationalized through a five point plan consisting of a coordinated international recovery and sustainable growth plan focused on job creation: public investment and social protection for the most needy; nationalization of banks that are insolvent and establish new rules and machinery of governance to control global finance; extending the role of collective bargaining to offset the risk of wage deflation and reverse income inequality; policies to promote environmental sustainability and green growth; and establishing a 'legal benchmark of norms and instruments of the international economic and social institutions - the ILO, IMF, World Bank, WTO, and the OECD' (ibid: 3). While often lacking in specificity the proposals would add up to change in the global economic system. 


\section{Conclusions}

Documents emerging from the outsider track of labour's strategy are clearly more radical that those developed in the insider track. However, in a number of aspects these ideas are also quite limited and reflect the prevailing orthodoxy. There are very real constraints imposed by the insider strategy as well. On trade, for example, the incorporation of workers' rights and recognition of the legitimacy of limited capital controls by developing countries hardly reverses the power asymmetries embedded in the global trading system (see Wilkinson 2011). Similarly, the proposal to use international organizations' norms and decisions as some sort of enforceable legal benchmark fails to recognize the degree to which these organizations have reflected and even instigated the neoliberal paradigm. While the proposal that working people have a 'seat at the table' (London Declaration: 10) in the new global institutions would be an advance on the existing situation, the analogy with the role played by the TUAC at the OECD is hardly encouraging as, notwithstanding the valuable role played by the TUAC in other contexts, it is largely marginalized within the inner sanctums of the OECD. Similarly, the call for the ILO to be 'at the centre of a new multilateral architecture that can respond effectively to the current crisis in market-driven globalisation by placing employment, social priorities and the promotion of decent work at the heart of decision-making' (p.10) is aspirational but does not confront the organizational and political inadequacies of the ILO as articulated by critics such as Guy Standing (2008).

According to Standing, the ILO's focus on 'soft law' and norms-based conventions to the detriment of bridging labour inequality led to the organization's progressive marginalization from core labour market issues even as it continued to seek enhanced access to other institutional circles, for example at the G20 in 2009. For Standing, the Decent Work agenda at the heart of the ILO's 1999 platform falls short of a vision for global labour; instead, the concept leaves 'too much room for flabby platitudes' open to challenge by bodies like the International Organization of Employers. "The organisation has retreated into a nonconfrontational mode that sidelines equality while espousing the vagueness of "decency," "fairness" and "dialogue". ${ }^{18}$ The trouble is that if the ILO cannot address, and does not wish to address, the ideological issues...it is unclear what role it can play' (Standing 2008: 356-7, 368-70).

Clearly, global labour's objectives run counter to the outcomes of the prevailing neoliberal model. Yet, despite the radical aspiration to develop an alternative, there are indications that key ingredients of the neoliberal model are either poorly understood or at least not emphasized as part of the package for paradigm change. This leaves global labour's alternative looking less than fully developed and showing some signs of being in the hybrid location identified in Chart 1 or the Contested Zone of Chart 2. Examples include the failure to fully confront the implications of the architecture of the international trading and investment system (for accounts that identify problems see Van Harten 2005, McBride 2006, Wilkinson 2011). ${ }^{19}$ One explanation for labour's lack of emphasis on these issues is that they no longer feature on the agenda of the organizations labour is seeking to influence, and are simply a reflection of priorities in a crisis situation. ${ }^{20}$ Similarly, there is a selective analysis of the limits of international organizations, such as the ILO and OECD, where 
labour enjoys representation. This is reflected in acceptance of, for example, the OECD (2006) rethink of its Jobs Strategy (for a more critical analysis see McBride, McNutt and Williams 2008). ${ }^{21}$ In another example, the implications for labour of the OECD's longstanding promotion of capital mobility (see Williams 2008) are rarely mentioned while efforts are made to promote and reference the OECD Guidelines on Multinational Enterprises, which are recommendations and not legally enforceable (OECD 2011: 4).

In terms of effectiveness, however, it is also clear that labour's structural weaknesses precluded its message from making much headway in the forums it chose to influence. Unsurprisingly, the G20 Labour Ministers proved more receptive than their Finance Minister counterparts. High profile communiqués issued by the G20 leaders (G20 Leaders 2008, 2009a, 2009b, 2010a, 2010b, 2011, 2012) on issues related to unemployment, job creation, and society's most vulnerable, may reflect the influence of labour's lobbying efforts. Yet they were modified by the advice from the Finance Ministers, which, from 2009 emphasized a reduction of stimulus, fiscal consolidation, deficit reduction, reduction of debtto-GDP ratios, structural labour market reforms, and measures to buttress investor confidence. In terms of Charts 1 and 2, neoliberal orthodoxies were being re-asserted and, as in the case of European peripheral states, intensified under the direction of the Trioika (the European Central Bank, European Commission, and the IMF) or autonomously as under the coalition government in the UK.

The crisis represented an opening and an opportunity for discussion of alternatives to the prevailing paradigm that has served labour, at least in the developed world, so ill over the past thirty years. But the opportunity found labour at a considerable disadvantage. Paradigm change implies both a set of alternative ideas and social forces strong enough to contend on behalf of new ideas with those backing the old. The durability of the neoliberal globalization project has little to do with the power of its ideas - increasingly these are exposed as threadbare - but rather in the power of the bloc of state and social forces that promote and benefit from it. Jessop (2012: 27) notes: 'Powerful narratives without powerful bases from which to implement them are less effective than...accounts that are pursued consistently by the powerful through the de facto exercise of power'. This means that debates over alternatives hardly take place on a level playing field. This judgement certainly fits the case of global labour's efforts to devise an alternative to the neoliberal paradigm.

Labour is structurally weak after decades of neoliberal globalization. Its industrial strength, as measured by union density, has steadily declined for a protracted period. Its political allies are either ineffective or thoroughly integrated into the dominant paradigm. There remain areas of strength, and other opportunities for influence though works councils and other mechanisms of social dialogue and co-determination. Yet the impact of these remains limited and, perhaps more importantly from the point of view of broader paradigm change, there are no discernible divisions in the ranks of capital which could serve as the basis for cross-class alliances or compromises. Capital remains remarkably united around the main principles of neoliberalism and it is unclear at this juncture what, if any, new alliances will be formed between labour and various social forces battling austerity policies in Europe and elsewhere. 
However, from a position of structural weakness labour has clearly sought to take advantage of the opportunities it does have available to it. In promoting alternative ideas to resolve the crisis on terms more favourable to labour, we have focused on two principal strategies. The first has been to try and influence policy positions and advice provided by international organizations, the ILO and OECD, in which labour, as a result of its strength in previous eras, enjoys representation. A second strategy has been to lobby global organizations like the IMF, G8 and G20 - organizations that are making decisions and recommendations that have a major effect on the course and outcome of the crisis.

The first strategy involves promotion of the claims of the ILO and, to a lesser extent the OECD, to be taken seriously, listened to, and perhaps structurally incorporated more effectively in the global governance architecture. The approach is beset with contradictions. Labour does have influence in these organizations, though arguably very limited in the case of the OECD which routinely recommends policies hostile to labour interests, as with the flexibility theme of the Jobs Strategy. Even within the ILO, labour is a minority voice and the achievement of pronouncements favouring labour rights is surrounded by vague language and non-enforceability.

As outsiders lobbying the powerful, global labour has promoted alternative ideas, though these are sometimes rendered excessively cautious by a felt need to build upon what was achieved in its capacity as an insider. Thus, for example, the ILO's Global Jobs Pact features in many labour policy statements despite its vagueness and moderation.

Over time, as the crisis has developed, global labour's rhetoric became more radical and included calls for paradigm change. Although the proposed changes were sometimes significant - such as more stimulus spending, more protection of labour and social rights, more controls on finance - these changes in reality do not add up to a fundamental rejection of the neoliberal paradigm, nor a comprehensive alternative to it. This is especially clear in the treatment of trade and investment agreements that, outside demands for stricter regulation of finance, leaves intact the combination of capital mobility and free trade that has been so lethal to the interests of labour in the neoliberal era. Global labour officials are acutely aware of the need for pressure on governments from organized labour and its allies if alternative proposals are to make any headway. And the strategies labour has used are sometimes depicted in a Gramscian sense as a struggle for hegemony:

organized labour, political movements, and critical academic research and thinking, and also media and journalism [are involved in] trying to change the hegemonic discourse...the ILO has the opportunity to bring some arguments for...the kind of macroeconomic policies conducive to growth, which we can bring into the debate...it's a complex process and you need alliances (confidential telephone interview, ILO official, 7 November 2012).

The neoliberal project is, of course, more than a policy paradigm. It is a capital accumulation strategy designed to fix problems encountered by capital. Labour and its social movement allies have proven capable of considerable resistance and sometimes successful 
defence of the pre-neoliberal order. It is, of course, possible that successive rounds of austerity and coercion will galvanize these social forces, but presently they seem too weak to displace capital from its dominant position in contemporary society, and it is many years since any hint surfaced that this was their goal. Nor, since the demise of Keynesianism, has anyone constructed a new 'middle way' in which capital's self-defined accumulation needs, or those of some fraction of capital, could be reconciled with a more just and secure social order, even though the numerous benefits of the attributes of such a society, such as equality, have been amply proven (Wilkinson and Pickett 2010).

\section{NOTES}

1. Stephen McBride is grateful for research funding from SSHRC (Standard Grant number: 410-2010-0837) and the Canada Research Chairs program and the research assistance of Scott Leon. Previous versions of this paper were presented at the AIRAANZ conference (Gold Coast, Queensland, February 2012) and the Canadian Political Science Association conference (Edmonton, June 2012). We are grateful for feedback and suggestions received from participants at those sessions, from Jane Jenson our discussant in Edmonton, and from the journal's two anonymous reviewers.

2. In this paper we focus on the International Trade Union Confederation (ITUC) and the Trade Union Advisory Committee to the OECD (TUAC). Both are linked to a number of other global labour organisations like the Global Union Federations (GUFs), the Council of Global Unions (CGU) and the Global Union Research Network (GURN) and interact closely with labour representatives at the International Labour Organisation (ILO).

3. 'Unions Welcome Apparent Shift by the G8 from Austerity to a Focus on Growth and Jobs' (21 May 2012). Accessed online on 21 May 2012 at ITUC website: http://www.ituccsi.org/unions-welcome-apparent-shift-by.html.

4. All members except the UK and the Czech Republic.

5. Meanwhile part of the intellectual case for austerity was undermined with the revelation that a widely cited and influential article had simply got its numbers wrong and the posited effects on growth of public debt reaching a tipping point at 90 percent of GDP had been vastly exaggerated. Yet this exposure had little impact on those committed to austerity policies (for a brief overview see http://www.guardian.co.uk/politics/2013/apr/18/uncoverederror-george-osborne-austerity). 
6. As Dean Baker (2011) and others have pointed out, counterposing state and markets in this way can be misleading as neoliberals also rely on the state, but for different purposes than their Keynesian predecessors.

7. Blyth (2001: 2) makes the case that times of uncertainty, such as economic crises, are not resolved purely by structural forces. Ideas matter, and path dependence can be an ideational as well as an institutional phenomenon. Thus dominant ideas define what is possible and, until successfully challenged and displaced, are likely to resemble or build upon the status quo - even if such ideas and policies and those based on them make literally 'no sense' (Blyth 2001: 24).

8. For a sophisticated review of the literature on policy paradigms and paradigm shifts see Skogstad and Schmidt, 2011.

9. This is not to deny, as Mark Blyth (2001:2) has pointed out, that the battle of ideas can just as easily lead to continuity and reinforcement of dominant paradigms as to their replacement. Still, his conceptualization of economic ideas as institutional blueprints during periods of uncertainty, as weapons in distributional struggles, and as "cognitive locks" usefully leads, in our view, to a simultaneous emphasis on the social forces espousing ideas, as well as on the ideas themselves.

10. Global union officials contrasted the more positive outcomes they had achieved at the G20 with the less successful attempts to influence the European Commission (confidential telephone interview, ITUC official, 12 July 2012).

11. Though we note in passing that the inclusion of social or labour clauses hardly represents an effective response to the challenges that neoliberal trade and investment agreements pose to labour's interests and thus leave labour badly positioned in terms of developing an alternative paradigm.

12. Defined by Standing (2010: 314) as leaving 'structures in place while developing a rhetoric that is non-threatening to powerful interests while seeming to be on the side of the poor, vulnerable and disadvantaged'.

13. See ILO website: http://www.ilo.org/global/about-the-ilo/decent-work-agenda/lang-en/index.htm.

14. See ILO website: http://www.ilo.org/actrav/info/pr/WCMS_178680/lang-en/index.htm.

15. Council of Global Unions minutes from January 2010 meeting: http://www.globalunions.org/IMG/pdf/02-Minutes_CGU_Jan10.pdf. 
16. 'The IFIs and G20 Must Lead a Global Action Plan to Prevent a New Surge in Unemployment'.

17. Getting the World to Work, p. 23

18. For a review of various critiques of the ILO, including that of Standing, see Haworth and Hughes, 2011: Ch.8.

19. Another example is the role of central bank independence (which is unlikely to be much moderated by the proposal to require them to engage in structured dialogue with other social forces, besides finance, which arguably enjoys privileged access under conditions of central bank independence).

20. One of our interviewees (confidential telephone interview, ITUC official, 17 July 2012) did outline a global labour agenda beyond inclusion of social clauses in trade agreements. It included support for greater controls on capital mobility including a Tobin tax, opposition to certain types of intellectual property rights, and defending developing countries' sovereignty to adopt industrial policies. However, in the present context it does not receive much public profile.

21. An explanation could be that the rethink did represent progress when compared to the original strategy against which global labour organizations had waged a long campaign. And if only partially successful this was, at least, a victory of sorts.

\section{REFERENCES}

Baker, D. (2011) The End of Loser Liberalism: Making Markets Progressive. Washington, D.C.: Center for Economic and Policy Research.

Blyth, M. (2001) 'The Transformation of the Swedish model: Economic Ideas, Distributional Conflict, and Institutional Change', World Politics 54(1): 1-26.

Endres, A.M. and Fleming, G. (1996) 'International Economic Policy in the Interwar Years: The Special Contribution of ILO Economists', International Labour Review 135(2): 207-225. 
European Trade Union Institute (2011) Exiting the Crisis: Towards a Model of More Equitable and Sustainable Growth. Brussels: ETUI.

G20 Leaders (2008) 'Declaration of the Summit on Financial Markets and the World Economy', available at: http://www.g20.utoronto.ca/2008/2008declaration1115.html. [Accessed 24 June 2013].

G20 Leaders (2009a) 'Global Plan for Recovery and Reform', London Summit, available at: http://www.g20.utoronto.ca/2009/2009communique0402.html. [Accessed 24 June 2013].

G20 Leaders (2009b) 'G20 Leaders Statement: The Pittsburgh Summit', available at: http://www.g20.utoronto.ca/summits/2009pittsburgh.html. [Accessed 24 June 2013].

G20 Leaders (2010a) 'The G20 Toronto Summit Declaration', available at: http://www.g20.utoronto.ca/summits/2010toronto.html. [Accessed 24 June 2013].

G20 Leaders (2010b) 'The G20 Seoul Summit Leaders' Declaration', available at: http://www.g20.utoronto.ca/2010/g20seoul.html. [Accessed 24 June 2013].

G20 Leaders (2011) 'Communiqué: G20 Leaders Summit', available at: http://www.g20.utoronto.ca/2011/2011-cannes-communique-111104-en.html. [Accessed 24 June 2013].

G20 Leaders (2012) 'G20 Leaders Declaration', available at: http://www.g20.utoronto.ca/2012/2012-0619-loscabos.html. [Accessed 24 June 2013].

Global Union Federation (2009) Getting the World to Work: Global Unions' Strategies for Recovery. Brussels: Council of Global Unions.

Hacker, J.S. (1998) 'The Historical Logic of National Health Insurance: Structure and Sequence in the Development of British, Canadian, and U.S. Medical Policy', Studies in American Political Development 12(1): 57-130.

Hall, P. (1993) 'Policy Paradigms, Social Learning, and the State: The Case of Economic Policymaking in Britain’, Comparative Politics 25(4): 275-96.

Harvey, D. (2008) The New Imperialism. Oxford: Oxford University Press. 
Hennebert, M.A. and Bourque, R. (2011) 'The International Trade Union Confederation (ITUC): Insights from the Second World Congress', Global Labour Journal 2(2): 1549.

Hughes, S. and Howarth, N. (2010) The International Labour Organisation (ILO): Coming in From the Cold. London: Routledge.

Hughes, S. and Howarth, N. (2012) 'The International Labour Organisation and the Greek Crisis: Prospects for Social Dialogue and Labour Market Reform.' Paper presented at the $26^{\text {th }}$ AIRAANZ Conference, 8-10 February 2012.

Huijen, F., Whittall, M. and Knudson, H. (2007) 'Tackling the Identity Dilemma', in F. Huijen, M. Whittall and H. Knudson (eds) Towards a European Identity: The Case of the European Works Council (pp. 214-227). London: Routledge.

ILO (International Labour Organisation) (2009) Recovering From the Crisis: A Global Jobs Pact. Geneva: ILO.

ILO (2011) The Global Crisis: Causes, Responses and Challenges. Geneva: ILO.

ILO (2011b) Social Protection Floor for a Fair and Inclusive Globalization. Geneva: ILO.

ITUC (International Trade Union Confederation, Washington) (2010) 'Decisions Adopted by the $2^{\text {nd }}$ ITUC World Congress', Vancouver 21-25 June 2010, available at http://www.ituc-csi.org/IMG/pdf/CONGRESS_Decisions_EN.pdf. [Accessed 4 April 2012].

ITUC (2008) 'The Washington Declaration'. Trade union statement to the G20 Crisis Summit, available at http://www.ituc-csi.org/IMG/pdf/0811t_gf_G20.pdf. [Accessed 24 June 2013].

ITUC (2009) Trade Union Statement to the St. Andrews G20 Finance Ministers' Meeting, available at: http://www.ituc-csi.org/IMG/pdf/0911t_g20_standrews-2.pdf. [Accessed 24 June 2013].

ITUC (2010) 'Take Action on Jobs to Sustain the Recovery'. Statement to the G8 and G20 Ontario summits, available at: http://www.ituc-csi.org/IMG/pdf/FinalTrade_Union_Statement_to_G20_Toronto_.pdf. [Accessed 24 June 2013].

ITUC (2011) 'Global Unions' Statement to G20 Employment and Labour Ministers' Meeting', available at: http://www.ituc- 
csi.org/IMG/pdf/Global_Union_statement_G20_Labour_meetings.pdf. [Accessed 24 June 2013].

ITUC (2012) 'Job-focused Growth and Reduction of Inequality Must Become Priorities of the IFIs'. Statement by Global Unions' to the 2012 meetings of the IMF and World Bank, available at: http://www.ituc-csi.org/IMG/pdf/statement.imfwb.0412.pdf. [Accessed 24 June 2013].

ITUC (2013) Statement by Global Unions to the 2013 Meetings of the IMF and World Bank', available at: http://www.ituc-csi.org/IMG/pdf/lagardespring2013.pdf. [Accessed 24 June 2013].

Jessop, B. (2012) 'Narratives of Crisis and Crisis Response: Perspectives from North and South', in P. Utting et al (eds), The Global Crisis and Transformative Social Change (pp. 23-42). Basingstoke: Palgrave.

Kuhn, T.S. (1962) The Structure of Scientific Revolutions. Chicago: University of Chicago Press.

Lansbury, Russell D. 'Work and Industrial Relations: Towards a New Agenda', Relations industrielles/Industrial Relations 62(2): 326-339.

McBride, S. (2006) 'Reconfiguring Sovereignty: NAFTA Chapter 11 Dispute Settlement Procedures and the Issue of Public-private Authority', Canadian Journal of Political Science 39(4): 755-775.

McBride, S., McNutt, K. and Williams, R. (2008) 'Policy Learning? The OECD and its Jobs Strategy', in R. Mahon and S. McBride (eds), The OECD and Transnational Governance (pp. 152-169). Vancouver: UBC Press.

Munck, R. (2002) Globalization and Labour: The New 'Great Transformation. London: Zed Books.

OECD (Organisation for Economic Cooperation and Development) (1994) The Jobs Study: Facts, Analysis, Strategy. Paris: OECD.

OECD (1996) The OECD Jobs Study: Implementing the Strategy. Paris: OECD.

OECD (2007) Society at a Glance: OECD Social Indicators. Paris: OECD.

OECD (2008) Guidelines for Multinational Enterprises. Paris: OECD. 
Peters, J. (2011) 'The Rise of Finance and the Decline of Organised Labour in the Advanced Capitalist Countries', New Political Economy 16(1): 73-99.

Pierson, P. (2000) 'Increasing Returns, Path Dependence, and the Study of Politics', American Political Science Review 94(2): 251-267.

Schmidt, V.A. (2011) 'Reconciling Ideas and Institutions Through Discursive Institutionalism', in D. Béland and R.H. Cox (eds), Ideas and Politics in Social Science Research (pp. 47-64). Oxford Scholarship Online.

Skogstad, G. and Schmidt, V.A. (2011) 'Introduction: Policy Paradigms, Transnationalism and Domestic Politics', in G. Skogstad (ed), Policy Paradigms, Transnationalism and Domestic Politics (pp. 3-35). Toronto: University of Toronto Press.

Standing, G. (1998) 'The ILO: An Agency for Globalization?', Development and Change 39(3): 355-84.

Standing, G. (1999) Global Labour Flexibility. London: Macmillan.

Standing, G. (2010) 'Global Monitor: The International Labour Organisation', New Political Economy 15(2): 307-318.

Stiglitz, J. (2011) 'Rethinking Macroeconomics: What Went Wrong and How to Fix It', Global Policy 2(2): 165-175.

TUAC (Trade Union Advisory Committee) (2008) 'Responding to the Global Crises: The

Role of the G8'. Trade Union Statement to the G8, available at: http://www.tuac.org/en/public/e-docs/00/00/02/30/document_doc.phtml. [Accessed 24 June 2013].

TUAC (2009) 'A Stronger, Cleaner, Fairer World Economy'. TUAC Statement to the OECD Ministerial Council, available at: http://www.tuac.org/en/public/edocs/00/00/02/30/document_doc.phtml. [Accessed 24 June 2013].

TUAC (2010) 'Road to Recovery, Innovation, Jobs and Clean Growth'. TUAC Statement to the OECD, available at: http://www.tuac.org/en/public/edocs/00/00/06/E3/document_doc.phtml. [Accessed 24 June 2013].

TUAC (2013) 'It's All About People: Jobs, Equality and Trust'. TUAC Statement to the OECD Ministerial Meeting, available at: http://www.tuac.org/en/public/edocs/00/00/0C/C8/document_doc.phtml. [Accessed 24 June 2013]. 
Van Harten, G. (2005) 'Private Authority and Transnational Governance: The Contours of the International System of Investor Protection', Review of International Political Economy 12(4): 600-623.

Vosko, L.F. (2000) Temporary Work: The Gendered Rise of a Precarious Employment Relationship. Toronto: University of Toronto Press.

Vosko, L.F. (ed) (2005) Precarious Employment: Understanding Labour Market Insecurity in Canada. Montreal and Kingston: McGill-Queen's University Press.

Wilkinson, R. (2011) 'Measuring the WTO's Performance: An Alternative Account', Global Policy 2(1): 43-52.

Wilkinson, R.G. and Pickett, K. (2010) The Spirit Level: Why Equality is Better for Everyone. London: Penguin Group.

Williams, R.A. (2008) 'The OECD and Foreign Investment Rules: The Global Promotion of Liberalization', in R. Mahon and S. McBride (eds), The OECD and Transnational Governance (pp. 117-133). Vancouver: UBC Press.

\section{BIOGRAPHICAL NOTE}

STEPHEN MCBRIDE is Canada Research Chair in Public Policy and Globalization and Professor of Political Science at McMaster University. His current research focuses on the politics and policies of austerity. [email: mcbride@mcmaster.ca]

SCOTT SMITH is a doctoral candidate in the Department of Political Science at McMaster University. His doctoral research focuses on OECD education governance in non-member economies. [email: smiths66@mcmaster.ca] 